\title{
Colorectal Cancer pT3 TNM Finding v7
}

National Cancer Institute

\section{Source}

National Cancer Institute. Colorectal Cancer pT3 TNM Finding V7. NCI Thesaurus. Code C89945.

Colorectal cancer with invasion through the muscularis propria into pericolorectal tissues. (from AJCC 7th Ed.) 